Journal of English Language Teaching

UNNES

\title{
Identifying the teaching of English to early young learners at Stepping Stones School Surabaya
}

\section{Margareta Desi Restuti ${ }^{\bowtie}$}

Stepping Stones School Surabaya, Indonesia

\begin{tabular}{l} 
Article Info \\
\hline Article History: \\
Received in 8 \\
December 2020 \\
Approved in 16 March \\
2021 \\
Published in 26 March \\
2021 \\
\hline Keywords: early young \\
learners; teaching \\
English; TEYL
\end{tabular}

\begin{abstract}
In Indonesia, learning English becomes one of the important parts of the process of learning at the school. There are notes to be considered in introducing English as a Second Language to young learners. The research was conducted to find out that there are key factors to be considered dealing with teaching English to early young learners. As a qualitative descriptive case study research, the research was conducted at Stepping Stones School Surabaya as it is a school for very young learners. The method of the research is qualitative descriptive research. The research found out that a full English school and a school with a fun learning environment are important for young learners. Besides identifying the key factors of teaching English to young learners, the research also aims to identify the underlying methods of teaching English at the Stepping Stones School Surabaya as the school has a preschool and kindergarten level program with a well-designed curriculum; the school also support the programs with well-qualified teachers; the school pays attention to the age of the students especially in applying the full English method; the school involves the parents to be in part of the learning by having similar ways in treating the children at home. This research was conducted as a way to give insight, especially to the opinion of worrying about introducing English as a second language too early young learners and for the parents who do not have English skills to accompany their children's process of learning.
\end{abstract}




\section{INTRODUCTION}

The influence of English in Indonesia can not be prevented, (Sadtono, 2013) English has become a subject in lessons of the educational process of the students in Indonesia that was managed by the state through the Educational Ministry (Septy, 2000). The experience of the researcher shows that the curriculum of the school and the teacher's role are important to apply the curriculum (Restuti, 2017) of teaching English to Indonesian students especially the young learners. For example, one of the characteristics of the early young learners is they have a short attention pan, here the teachers should makea creative lesson where it shows the various activities to be presented or done together with the children. The curriculum of the school must consider this as a very important thing then the teacher must apply it in daily based planning and teaching. The other characteristics of early young learners are enjoying imitating and are skillful in listening accurately so the teachers should master English especially in the term of pronunciation that the learners are accustomed to hearing the correct pronunciation of English words. This supports the statement that language (English) is a good example of an area in which children come to preschool and the importance of teachers' role to recognize the language children have and to provide the use of the language with its growth and meaningful conversation so the children have many opportunities during the preschool to interact with new peers and adults (Clark, 2000).

Meanwhile, many people realize that English has become an important language to be used nowadays school should consider carefully how to teach English to the students, especially to the young learners. There were questions and worries if English is introduced earlier to the students such as an opinion that the English teaching would ruin the first language acquisition of the early young learners, while as stated that the children's brain is programmed to learn the language (Matthews, 2005). About teaching English to young learners especially in Indonesia, other researchers have found out important findings such as the teachers teaching English to young learners in Lampung were not ready to teach English that they teach English fully in Bahasa Indonesia (Apriliana, 2018). The findings of the previous researchers mostly about the readiness of the teacher that they need further training in the using of English though those teachers were confident enough to teach English to the young learners (Mutiah et al., 2020) as also stated by the other researcher (Nufus, 2019). In West Sumatra, a researcher found out that there were some essential requirements in teaching English to young learners such as curriculum, teacher competency, media, and method used (Pransiska, 2016). Another researcher also highlighted the teachers' readiness in teaching English to young learners in the field of pedagogical values that the teacher should know the principles and should be able to do things to facilitate children learning English as a foreign language in Indonesia by determining who children are, how children learn, how children learn a language, and how children learn English as a Foreign Language (Musthafa, 2013). The researcher expected that the research would help on how to teach English to early young learners especially the technical things to be done and applied in teaching English to young learners in Indonesia as a portrait at the Stepping Stones School of Surabaya that has run the system since the year of 2000. One of the researcher's experiences at the Stepping Stones School was she found that the children did not find it difficult to speak Bahasa Indonesia while they are exposed to English fully at school from a year old to four years old of age.

\section{Literature Review}

The research was conducted to find out the key factors of teaching English to young learners at Stepping Stones School Surabaya by describing the teaching English at the school and the key factors underlying the methods of it.

To support the research, there were many literature reviews about teaching English and young learners. About the young learners, Montessori has become an important expert to be cited that she said that education is to be focused on the children to help them during the development in the process to be a complete adult human being that has the competence and to contribute to the society and humanity generally. The Montessori approach is centered on supporting the human being's natural development. This concept could support the development of language in young learners especially about English (Restuti, 2017). Other expert stated that in the areas of vision, hearing, social attachment, language, motor skills, math/ logic, music, and foreign languages where the windows of opportunity for brain development, and so there are important things to be done to develop the children's capacities to guide them to bea fine adult (Stiles \& Jernigan, 2010).

Montessori has thought about the substance of the human being including the integration of the character development and the whole personality that should be instilled into the child. This has 
changed the paradigm of education for centuries especially that the children could guide their development, even to guide the educators in supporting the children (Nicholas, 2014).

Montessori stated that the role of the adults is to help the children meet their potential. Montessori supported the idea that the children possess great constructive energies that would support the formation of the children's mind and body. Montessori's approach has been seen as the appropriate tool to develop education for early young learners (Sacks \& Ruzzi, 2005). One of the results of the approach is that the children should become the center of the education process such as the class and its environment should support the children, for example with the multi-sensory equipment, and enough space for motor development. Those are to provide rich experiences to support the 'wiring' process in the children's brain. In early education for young learners, a school should provide a suitable curriculum to fully support the children's growth and development. The curriculum should provide the multi-sensory experience with repetition that would strongly support the brain connections (Matthews, 2005).

A discussion about teaching English as a Second Language can be related to bilingual education where the use of languages focused on the teaching of subject matter content, not merely the use of the language itself (Damico, 2010). In that book section, Cummins (2010) explained that there are types of bilingual educations focusing on the goals of the program, organizational structures, and characteristics of students in the program.

According to Cummins, bilingual education carries a positive impact on the children especially on the aspect of the development of linguistic of the children involved in the program and on the aspect of the development of the children's education themselves. He concluded that the positive development could be seen in the children continuing to develop their abilities in two or more languages, it has been comprehended through the program that has been followed by the children since their primary level including the early learner stage of the education. The benefit of the program could be seen in the term of gaining a deeper understanding of the used language and how to use the language effectively. The children have the chance to process the language, to apply the language in the literacy process in both languages. The children also would be able to compare and contrast the ways of using both languages separately in daily practice. The result of the bilingual program has supported what Goethe ever stated that the person who knows only one language does not truly know the language (Cummins, 2001). On the other hands, bilingual children develop more flexibility in the way they are thinking as a result of information processing the experiences, they have in a bilingual education program.

The stage of human growth and development that now becomes a very important thing is the young stage of human or even the early young stage of human being development. Many countries are now (or has paid) attention to anything needed to deal with the early young generation.

Human development especially brain development is very significant to determine someone's future. It happens dominantly in the Golden Age of an individual. It was mentioned that the foundations for thinking, language, vision, attitudes, aptitudes, and other characteristics are laid down during the preschool period especially the first three years of life (Kotulak, 1997). .

The other experts mentioned the importance of the early life of the human being especially during the first ten years of life especially related to the development of the language at the acquisition stage. Once again it was related to the development of the brain, the 'wiring' process that could be happening in the sound aspect of the language. Again the repeated exposure of the language becomes an important aspect in this stage. It was also noted that the existence of the adults around the children play a very important role in the children's language development and so the brain development (Graham \& Forstadt, 2011).

The role of English as a Second Language will innate the children's ability to use the language when the language is presented within a context that is meaningful and communicative. The environment for L1 and L2 acquisition can be quite different although children may use similar processes for acquiring L1 and L2 (Karavas, 2010). So, in teaching L2, the teacher needs to remember to provide the language itself in very rich contexts that are meaningful and communicative. As required that the teaching should provide highly contextualized language, the use of authentic language in the real world, and the highly motivated learners; as the young learners can learn L1 (Restuti, 2017). 


\section{METHODS}

The research design refers to a qualitative descriptive case study research that this research focuses on covering the background information and accurate descriptions of the tcase in question (Johansson, 2007). The purposes of this research are mainly stated as to describe the teaching of English to young learners at the Stepping Stones School Surabaya and to describe the key factors underlying the methods of teaching English at the Stepping Stones School Surabaya.

The source of data of the research was from the documents of the school, the students, the parents of the students, and the teachers of the school. Parents are the closest resources to observe and to realize the children's development on the students. They are not only the parents of the current students but some parents are the parents of the alumni (Baxter \& Jack, 2008).

The data resources were the school documents, the recorded interview with some parents of the students, and also the teachers. There were also the parents' notes and observations when they attend the Open Class Program. There was an important thing related to the research that the researcher has got permission from the school founder and the school manager to reveal the name of the school in the research and its related publication.

The unit of analysis is related to the fundamental problem of defining the case; that the case might be an individual or individuals that might also involve the influence of early childhood or the role of peer relationship; the case also can be some events, decisions, programs, the implementation of process and about organizational change (Yin, 2013), the unit of analysis of this research would cover the key factors of teaching English to young learners at the Stepping Stones School Surabaya: the school curriculum, the teaching by the teachers, the learners' experience, the classroom context, the materials and resources, the learners and the parents of the learners.

There are many approaches in the way of teaching English to young learners. The most important thing is the fun things, young learners should have fun with English (Kang Shin, 2006), here, the design of the teaching is important. Hence curriculum of the Stepping Stones School and the way teachers plan the English teaching would become one of the units of analysis to this research. The curriculum would cover also the learning and teaching style at Stepping Stones School Surabaya especially that the tagline of the school is Where Learning is Fun. As mentioned, that the curriculum should emphasize communicative competence in teaching English to young learners (Copland \& Garton, 2014).

Many aspects that should be seen and considered deeply such as approaches to language teaching, recruitment, and training, teacher's level of English proficiency, the classroom context, examinations and assessment, materials and resources, learners (Garton et al., 2013), beside the curriculum represented by the school documents of the Stepping Stones School of Surabaya, there would be the teachers' comment about the Stepping Stones School, the parents' comments about the Stepping Stones School and the students of Stepping Stones School itself, the students' learning result, and the field observations that also covers the class observations done at the Stepping Stones School as the unit analysis of this research.

To sum up the methods of the research, here are the steps were taken by the researcher: 1) Read and comprehend the school documents as the guidance of the curriculum of the school. 2) Observed the running of the class to see how the teachers plan and conduct the class. 3) Conducted discussion and evaluation with the teachers about the running of the class. 4) Together with parents the researcher observed the running of the class of the school. 5) Conducted discussion and evaluation with the parents about the running of the class. 6) During those observations, the researcher also observed the students of the school. 7) The researcher did the data analysis.

\section{Subjects/ Participants}

The subjects of the research are the students, the parents, and the teachers of Stepping Stones School Surabaya. In 2017 there were around 70 students at the school with 15 teachers involving in the educational process at the school.

\section{Instruments}

The instruments that were used in the research area in a form of taking notes upon the related documents: the school documents that cover the curriculum and the learning result of the students. Other note-taking would be also about the field observation that covers the class observation (Baker, 2006) and (Allen, 2017). Here the students became the observation target when the researcher took notes about the students' performance, attitude, response, knowledge, language skills, habit, and 
relationship with peers, teachers, parents, and other people at the school. The other instrument would be on interview guidance or questions for the parents beside the form of observation with certain theme or rubrics of evaluation or assessment related to the application of the curriculum of the school specially to facilitate the students' learning and the school already have those documents as the school property that the researcher adopted from the literature and reflected them into research object. The researcher expected that those instruments would help the researcher to get suitable data for the research.

\section{Data collection procedures}

To conduct this research, the data collection procedures done by the researcher were: 1) the researcher collected the data by reading and comprehending the school documents since 2011 about the school. 2) The researcher also collected the data using a scheduled observation and the incidental observation to the classes of the school. 3) There was the recording of the interview to parents and the teachers that would be the data collection of the research. 4) The observation was done by recording the class activity and taking notes during the observation of the class.

In terms of the rubric of evaluation used during the Open Class Program, the questions or the rubric have been prepared as the school property. The Open Class program was conducted every 3 months with random parents to be invited. The invited parents came to attend the process of learning of each class in a day. The parents might observe and give notes about the whole activities in the class including the interaction between the teachers and the children, the teachers' preparation, and also the teacher's language fluency. Then the parents might fill the form based on their observation as the result of an evaluation or in case input for the teacher specifically and to the school generally. This data collection was the activities done by the researcher since 2011 when she joined the school and needed to know and comprehend the school well.

\section{Data analysis}

The data analysis activity was to analyze the primary data and the secondary data. The primary data that the researcher got was the result of observations of the class including the observation of the students, discussion, and evaluation result with the teachers and the parents of the students. The secondary data was documents both the documents about the Stepping Stones School and the document from the government about early young learners' education.

\section{FINDINGS AND DISCUSSION}

Table 1. Findings of the Research

\begin{tabular}{lll}
\hline \multicolumn{1}{c}{ Finding 1 } & \multicolumn{1}{c}{ Finding 2} \\
\hline $\begin{array}{l}\text { Stepping Stones School Surabaya is a school } \\
\text { with a full English system. }\end{array}$ & $\begin{array}{l}\text { the school should become a high-quality } \\
\text { preschool program } \\
\text { to be a high-quality pre-school, one of the } \\
\text { important ways is that the schools for young } \\
\text { learners need qualified teachers. }\end{array}$ \\
\hline $\begin{array}{l}\text { Stepping Stones School Surabaya sets the } \\
\text { fun learning reflected in the entire program } \\
\text { of the school that can be found in its history } \\
\text { and profile. }\end{array}$ & $\begin{array}{l}\text { dealing with teaching English to young } \\
\text { learners, the schools themselves have to be a } \\
\text { full English school by considering the period } \\
\text { of age of the students to support the children } \\
\text { in having a rich English exposure } \\
\text { environment. } \\
\text { dealing with the young learners, the schools } \\
\text { need to remember to always involve the } \\
\text { parents of the students. }\end{array}$ \\
\hline
\end{tabular}

Following the characteristics of young learners, they enjoy imitating and are skillful in listening accurately; interpret meaning without necessarily understanding the individual word; understand 
language as units, not as separate words. It is important to provide a rich environment that exposes English more. It is also suitable to support the characteristics of early young learners who are very active and imaginative and enjoy learning through playing, acting, making, and doing.

That four key factors are underlying the methods of teaching English at the Stepping Stones School Surabaya, first, the school should become a high-quality preschool program, because the schools would cause positive long-term improvements in participants' school performance and social outcomes. The school should be ready with a very well-designed curriculum. A well-designed curriculum is a curriculum that is suitable for the early young learners, fulfills the young learners' needs, and research-based curriculum. Remember also that the brain wiring would be affected by the early interactions, so it is very important to give rich experiences to early young learners to have a great effect on their brain wiring by providing the required environment of learning for them. It is also a matter of fact that a child's brain is two and half times as active as an adult, this is important to do something not to lose the chance (Sacks \& Ruzzi, 2005). Second, to be a high-quality pre-school, one of the important ways is that the schools for young learners need qualified teachers. These teachers are the ones interpreting the curriculum to be daily based practices in teaching.

Moreover, as the main resource of the students, the teacher should have qualified English skills. There is evidence also that the non-native speaker teachers can be trusted to deliver a very good English skill as long as the teachers have qualified pronunciation, rich vocabularies, and the ability to deal with young learners. Third, dealing with teaching English to young learners, the schools themselves have to be a full English school in such period of the age of the students to support the children in having a rich English exposure environment. As stated, that preschools have the greatest impact on children living in poverty and those who do not speak English at home, there is evidence that the children have the capacities to learn English and to apply their English in communicative ways. There is no reason to be afraid that the students would undergo the loss of the first language skill because the right bilingual education would make the students master the languages well (Sacks \& Ruzzi, 2005). Fourth, dealing with young learners, the schools need to remember to always involve the parents of the students. The parents are the basic need for every child. By involving the parents, the schools communicate well with the parents, so the parents may have similar ways of treating the children at home. On the other hand, the parents have the right to know and comprehend things delivered by the schools to every child they send to the schools.

\section{Discussion}

In designing or conducting the teaching of English to young learners, it is important to pay attention to the characteristics of young learners. They are different from teenagers and adults (Bessie, 2014)) for example young learners have a short attention span. It is applied by the school that the teacher must be creative in designing their lesson plan where there are many activities to attract the students' attention and in order not to make the students get bored in the class with a specific period. Time becomes a very important consideration when the teachers designing their lesson plan as the daily based application of the school curriculum.

The next characteristic of young learners is understanding language as units not separate words, at the Stepping Stones School Surabaya, it is applied by providing the full English environment with fun learning where the teachers are challenged to design a creative lesson plan and apply it in the class activity.

Dealing with teaching English to young learners, schools for early young learners need to use the opportunity well. The school should become a high-quality preschool program. The schools would cause positive long-term improvements in participants' school performance and social outcomes (Sacks \& Ruzzi, 2005). The school should be ready with a very well-designed curriculum. A welldesigned curriculum is a curriculum that is suitable for the early young learners, fulfills the young learners' needs, and research-based curriculum. It is important to remember also that early interactions also affect brain wiring, so it is very important to create such an environment to support the early young learners to have their best experience to have a great effect to their brain wiring and it is also a matter of fact that a child's brain is two and half times as active as an adult, this is important to do something not to lose the chance of stimulation to wire the brain of early young learners.

To be a high-quality pre-school, one of the important ways is that the schools for young learners need qualified teachers. These teachers are the ones interpreting the curriculum to be daily based practices in teaching. Moreover, as the main resource of the students, the teacher should have qualified English skills. There is evidence also that the non-native speaker teachers can be trusted to deliver a 
very good English skill as long as the teachers have qualified pronunciation, rich vocabularies, and the ability to deal with young learners.

Dealing with teaching English to young learners, the schools themselves have to be a full English school in such period of the age of the students to support the children in having a rich English exposure environment. Preschools have the greatest impact on children living in poverty and those who do not speak English at home (Sacks \& Ruzzi, 2005). There is evidence that the children have the capacities to learn English and to apply their English in communicative ways. There is no reason to be afraid that the students would undergo the loss of the first language skill because the right bilingual education would make the students master the languages well.

The schools need to remember to always involve the parents of the students. The parents are the basic need for every kid. By involving the parents, the schools communicate well with the parents, so the parents may have similar ways of treating the children at home. On the other hand, the parents have the right to know and comprehend things delivered by the schools to every child they send to the schools.

\section{CONCLUSION}

The conclusion of the research as stated below as the methods of teaching English to young learners at Stepping Stones School Surabaya are full English schools with the fun learning process that is applied in all aspects of the educational process for the children. The important key factors to be considered as following: 1) The set of curriculums that consider the characteristics of early young learners including the certain ground rules, certain programs with the guidance of lesson plans and observation chart, the set of clear scope and sequence for each specific range of age of early young learners.2) The application of the curriculum by the competent teacher to reach the students' ability in using English and provide the fun process of learning. There was also discussion and evaluation among the teachers to provide the appropriate process of learning for the students besides the creative ways of the teachings to walk in line with the tag line of the school which is where learning is fun. 3) English environment. It is important to create an English environment for the young learners such as the lessons were delivered in English.4) Involving parents is a great resource of the process of learning and the most important support part needed by each child. 5) Get the research or information about young learners learning and teaching especially also the government document to make sure the path is taken by the school.

For teachers and future researchers dealing with teaching English to young learners the researcher would suggest some matters first, the well-designed curriculum for early young learners is very important to set a consistent and continuous learning environment such as the full English system. The curriculum also needs to be interpreted in daily based activities by the teachers. Involving the parents during the process of learning is also a crucial thing to do. The bilingual education research would help the researcher in understanding that properly learning other languages would not ruin the mother tongue is important for those who are interested in developing the teaching English to early young learners. It should be noted that there are some effects on this kind of education when school is trying to introduce more than one language in the classroom. It is also important to be remembered that bilingualism has positive effects on children's linguistic and educational development.

When children continue to develop their abilities in two or more languages throughout their primary school years, they gain a deeper understanding of language and how to use it effectively. They have more practice in processing language, especially when they develop literacy in both, and they can compare and contrast how their two languages organize reality (Damico, 2010). Researchers assured that when the bilingual education system is applied well, it will help the early young learners a lot such as on children's linguistic and educational development.

\section{REFERENCES}

Allen, M. (Ed.). (2017). Observations, Fieldwork, and Other Data Collection Introduction (pp. 104119). SAGE College Publishing.

Apriliana, N. (2018). The Implementation of Teaching English To Young Learners in Public Primary Schools in Pringsewu, Lampung Province, Indonesia. 3, 21-35.

Baker, L. M. (2006). Observation: A complex research method. Library Trends, 55(1), 171189. https://doi.org/10.1353/lib.2006.0045

Baxter, P., \& Jack, S. (2008). The Qualitative Report The Qualitative Report Qualitative Case 
Study Methodology: Study Design and Qualitative Case Study Methodology: Study Design and Implementation for Novice Researchers Implementation for Novice Researchers. Number 4 Article, 13(4), 12-13. https://nsuworks.nova.edu/

Bessie, D. (2014). Applied Linguistics to Foreign Language Teaching and Learning. An introduction to Applied Linguistics. National and Kapodistrian University of Athens, 1-11. http://opencourses.uoa.gr/courses/ENL6/

Clark, B. A. (2000). First-and second-language acquisition in early childhood. Proceedings of the Lilian Katz Symposium, Nov, 5-7. http://ceep.crc.illinois.edu/pubs/katzsym/clarkb.pdf

Copland, F., \& Garton, S. (2014). Key themes and future directions in teaching English to young learners: Introduction to the Special Issue. ELT Journal, 68(3), 223-230. https://doi.org/10.1093/elt/ccu030

Cummins, J. (2001). Bilingual Children 's Mother Tongue: Why Is It Important for Education? Jim Cummins University of Toronto. Sprogforum, 7(19), 15-20. http://www.iteachilearn.com/cummins/mother.htm

Damico, et al. (2010). The Handbook of Language and Speech Disorders Blackwell Handbooks in Linguistics. In Cognition (Vol. 25). http://www.ncbi.nlm.nih.gov/pubmed/21566632

Garton, S., Copland, F., \& Burns, A. (2013). Investigating global practices in teaching English to Young Learners. British Council ELT Research Papers Volume 1, 35-68. http://englishagenda.britishcouncil.org/sites/ec/files/British Council WEB pdf_0.pdf

Graham, J., \& Forstadt, L. A. (2011). Children and Brain Development: What We Know About How Children Learn. Cooperative Extension Publications, The University of Maine, 18.

Johansson, R. (2007). On case study methodology. Open House International, 32(3), 48-54. https://doi.org/10.1108/ohi-03-2007-b0006

Karavas, E. (2010). Applied Linguistics to Foreign Language Teaching and Learning. 1-69.

Kotulak, R. (1997). Inside the Brain: Revolutionary Discoveries of How the Mind Works. McMeel Publishing.

Matthews, J. (2005). Early Brain Development Research: Implications for Early Childhood Education. 1-15.

Musthafa, B. (2013). Teaching English to Young Learners: Through the Eyes of EFL Teacher Trainers. ELT Research Journal, 2(3), 95-110.

Mutiah, S. D., Nakhriyah, M., HR, N. H., Hidayat, D. N., \& Hamid, F. (2020). The Readiness of Teaching English to Young Learners in Indonesia. Jurnal Basicedu, 4(4), 1370-1387. https://doi.org/https://doi.org/10.31004/basicedu.v4i4.541

Nicholas, M. St. (2014). What is Montessori. December, 1. http://www.montessori.org.uk/what_is_montessori

Nufus, T. Z. (2019). Teaching English to Young Learners in Indonesia (Pros and Cons). English Language in Focus (ELIF), 1(1), 65. https://doi.org/10.24853/elif.1.1.65-70

Pransiska, R. (2016). Requirements of Teaching English for Young Learners: an Overview in Padang, West Sumatera. Igniting a Brighter Future of EFL Teaching and Learning in Multilingual Societies, 250-255.

Restuti, M. D. (2017). The Key Factors of Teaching English To Young Learners : A Case Study of The Stepping Stones School Surabaya [Master's Thesis, Widya Mandala Catholic University]. Widya Mandala Catholic University Surabaya Repository. http://repository.wima.ac.id/citations?view_op=view_citation\&continue $=/$ scholar\%3Fh $1 \% 3 \mathrm{Dpt}-$

BR\%26as_sdt $\% 3 \mathrm{D} 0,5 \% 26 \mathrm{scilib} \% 3 \mathrm{D} 1 \&$ citilm $=1 \&$ citation_for_view=wS0xi2wAAAAJ :2osOgNQ5qMEC\&hl=pt-BR\&oi=p

Sacks, L., \& Ruzzi, B. B. (2005). Early Childhood Education: Lessons from the States and Abroad, 2005. National Center on Education and the Economy, 000. 
https://proxying.lib.ncsu.edu/index.php?url=https://search.ebscohost.com/login.asp $\mathrm{x}$ ?direct $=$ true $\& \mathrm{db}=$ eric $\& \mathrm{AN}=\mathrm{ED} 522109 \&$ site $=$ ehost-live \&scope $=$ site

Sadtono, E. (2013). English Tsunami in Indonesia. Beyond Words, 1(1), 37-67. http://journal.wima.ac.id/index.php/BW/article/view/370/348

Septy, A. P. (2000). Assumptions and evidences about introducing English in Indonesian primary schools. International Journal: Language, Society and Culture. internalpdf://184.44.129.199/Azainil septy.pdf\%0Ahttp://www.educ.utas.edu.au

Stiles, J., \& Jernigan, T. L. (2010). The basics of brain development. Neuropsychology Review, 20(4), 327-348. https://doi.org/10.1007/s11065-010-9148-4

Yin, R. K. (2013). Applications of case study research. Applied Social Research Methods Series, 34, 173. https://doi.org/10.1097/FCH.0b013e31822dda9e 